\title{
Draps d'Areste (II). Extension de la classification, comparaisons et lieux de fabrication
}

\section{Sophie Desrosiers}

\section{(2) OpenEdition \\ 1 Journals}

Édition électronique

URL : https://journals.openedition.org/tc/334

DOI : $10.4000 /$ tc.334

ISSN : 1952-420X

Éditeur

Éditions de l'EHESS

\section{Édition imprimée}

Date de publication : 1 janvier 2000

ISSN : 0248-6016

\section{Référence électronique}

Sophie Desrosiers, «Draps d'Areste (II). Extension de la classification, comparaisons et lieux de fabrication », Techniques \& Culture [En ligne], 34 | 2000, mis en ligne le 26 octobre 2005, consulté le 29 septembre 2022. URL : http://journals.openedition.org/tc/334 ; DOI : https://doi.org/10.4000/tc.334

Ce document a été généré automatiquement le 29 septembre 2022.

Tous droits réservés 
Draps d'Areste (II). Extension de la classification, comparaisons et lieux de fabrication

Sophie Desrosiers 